\title{
Verification of PEMS measurement accuracy based on light vehicle emission test system
}

\author{
Gang Wang ${ }^{1, *}$, Chao Qian ${ }^{1}$, Guoliang Yang ${ }^{1}$, Ligui $\mathrm{Nan}^{2}$, and Haige $\mathrm{Yu}^{3}$ \\ ${ }^{1}$ Suzhou Automotive Research Institute, Tsinghua University (Wu jiang), Suzhou 215200, China \\ ${ }^{2}$ Isuzu Auto Co., LTD., Tokyo, Japan \\ ${ }^{3}$ Suzhou Hua ye Testing Technology Service Co., LTD., Suzhou 215200, China
}

Keywords: light vehicle, portable, emission testing, accuracy of measurement.

\begin{abstract}
For the requirements of the portable emission measurement system (PEMS) measurement accuracy for limits and measurement methods for emissions from light-duty vehicles(CHINA 6) ,based on the light-duty vehicle emission test system in steady-state conditions and WLTC conditions for PEMS gaseous pollutants, mass flow rate, particle number (PN) verify accuracy of measurement. The results showed that the relative measurement errors of $\mathrm{CO}, \mathrm{CO} 2, \mathrm{NOx}$, fuel consumption and mass flow rate were $-5.49 \%, 2.53 \%, 10.55 \%, 2.09 \%$ and $-2.79 \%$. The relative measurement errors of $\mathrm{CO}, \mathrm{CO} 2, \mathrm{NOx}$, fuel consumption and $\mathrm{PN}$ under WLTC condition were $6.67 \%, 2.54 \%, 12.96 \%, 2.37 \%$ and $-16.08 \%$, which meeting the requirements of the regulations.
\end{abstract}

\section{Introduction}

A large number of relevant studies at home and abroad have shown that laboratory emission test results cannot truly reflect the level of pollutant emissions during actual vehicle driving. In particular, the traditional laboratory test method with a specific working cycle as the core cannot truly reflect the vehicle's emission level. There is a large difference between the laboratory certification emission test results and the actual road emissions. ${ }^{[1-2]}$

The test results of the portable on-board emission measurement system (PEMS) can truly reflect the emission characteristics of the vehicle during actual driving ${ }^{[3-4]}$. In order to truly reflect the pollutant emission level of vehicles during actual driving, countries have successively applied PEMS to the actual road emission testing process ${ }^{[5-6]}$. The United States and Europe have successively applied PEMS to check the consistency of heavy-duty diesel vehicles (HDV) and non-road machinery in use. In 2005, the US Federal Environmental Protection Agency issued regulations requiring the use of PEMS for HDV gaseous pollutants for actual road testing and NTE (not-to exceed) analysis methods for emissions analysis ${ }^{[7]}$. The European Union announced the use of PEMS to measure the gaseous pollutants and particulate matter of heavy-duty vehicle engines and the gaseous pollutants of natural gas and liquefied petroleum gas ignition engines. Subsequently, PEMS was gradually incorporated into the driving certification of light-duty vehicles (LDV)

* Corresponding author: 18550057668@163.com 
emission regulations. The EU has developed light vehicle real driving emission (RDE) testing regulations, which were enforced in EU member states in September $2017^{[8]}$. In recent years, China has gradually applied the PEMS test method to the LDV, HDV, and non-road mobile machinery actual driving pollutant emission testing process ${ }^{[9-11]}$.

In view of the increasingly important role of PEMS in the actual driving pollutant emission control, and related regulations also put forward requirements for PEMS measurement accuracy, it is necessary to verify the PEMS measurement accuracy. This article uses a light vehicle emission test system to test the PEMS gas analyzer, flow measurement equipment, and particle number $(\mathrm{PN})$ on the chassis dynamometer under steady-state conditions and WLTC (Worldwide Light-duty Test Cycle) conditions. Verification of measurement accuracy.

\section{Test vehicles and main test equipment}

\subsection{Test vehicle}

This article selects a manual transmission car that meets the national $\mathrm{V}$ emission requirements as a test sample car. This car has been used as a daily comparison car in the laboratory, and the car condition is relatively stable. The test vehicle parameters are shown in Table 1.

Table 1. Vehicle parameters

\begin{tabular}{lc}
\hline \multicolumn{1}{c}{ project } & parameter \\
\hline Maximum power KW & 96 \\
Maximum torque Nm & 155 \\
The engine & $1.5 \mathrm{~L} 131 \mathrm{hp} \mathrm{L4}$ \\
Air intake form & Naturally aspirated \\
Fuel label & 92 \\
Ready mass $\mathrm{kg}$ & 1058 \\
\hline
\end{tabular}

\subsection{Main test equipment}

The main test equipment for this test includes a light vehicle emission test system, a full-flow dilution constant volume system, a chassis dynamometer, an emission environment silo system, and PEMS equipment.

PEMS equipment is manufactured by Japan HORIBA Company, model OBS-ONE-GS02. The system mainly includes a main control system (CC), a gas pollutant measurement unit (GA), a particulate matter measurement unit (PN), an exhaust gas flow measurement unit (PF), a weather station, GPS, and a vehicle OBD reading module, etc. The pollutant measurement unit mainly measures $\mathrm{CO}, \mathrm{CO} 2, \mathrm{NO}, \mathrm{NO}, \mathrm{NOx}$. The exhaust flow measurement unit uses a Pitot tube type flowmeter. Different sizes of flowmeters are suitable for different displacement test models. The basic parameters of PEMS are shown in Table 2 .

Table 2. Basic parameters of PEMS.

\begin{tabular}{cccc}
\hline $\begin{array}{c}\text { Measuremen } \\
\mathrm{t} \text { unit }\end{array}$ & Method of measurement & range & Accuracy of measurement \\
\hline $\mathrm{CO}$ & $\begin{array}{c}\text { Non-spectral infrared method } \\
\text { (NDIR) }\end{array}$ & 0 to $10 \mathrm{vol} \%$ & $\begin{array}{c}\text { Plus or minus } 0.3 \% \mathrm{FS} \text { or plus } \\
\text { or minus } 2 \% \mathrm{PT}\end{array}$ \\
$\mathrm{CO} 2$ & $\begin{array}{c}\text { Non-spectral infrared method } \\
\text { (NDIR) }\end{array}$ & $0-20 \mathrm{vol} \%$ & $\begin{array}{c}\text { Plus or minus } 0.3 \% \mathrm{FS} \text { or plus } \\
\text { or minus } 2 \% \mathrm{PT}\end{array}$
\end{tabular}




\begin{tabular}{|c|c|c|c|}
\hline $\begin{array}{l}\mathrm{NO}, \mathrm{NO} 2 \\
\mathrm{NOx}\end{array}$ & $\begin{array}{l}\text { Chemiluminescence (Dual } \\
\text { CLD) }\end{array}$ & 0-3000 PРM & $\begin{array}{c}\text { Plus or minus } 0.3 \% \mathrm{FS} \text { or plus } \\
\text { or minus } 2 \% \mathrm{PT}\end{array}$ \\
\hline The PN & $\begin{array}{l}\text { Condensate particle counter } \\
\text { 12. (Condensation Particle } \\
\text { counting, CPC) }\end{array}$ & $\begin{array}{l}0-50000 \# / \\
\mathrm{cm}^{\wedge} 3\end{array}$ & Plus or minus $10 \% \mathrm{PT}$ \\
\hline $\begin{array}{l}\text { Method of } \\
\text { measuremen } \\
t\end{array}$ & Wet base measurement & - & - \\
\hline $\begin{array}{l}\text { The exhaust } \\
\text { flow }\end{array}$ & Pitot Flow meter & $\begin{array}{c}0-65.0 \mathrm{~m}^{\wedge} 3 \\
/ \mathrm{min}\end{array}$ & $\begin{array}{c}\text { Plus or minus } 0.5 \% \mathrm{FS} \text { or plus } \\
\text { or minus } 2 \% \mathrm{PT}\end{array}$ \\
\hline
\end{tabular}

Table 3. MexA-7400DTR partial parameters.

\begin{tabular}{|c|c|c|c|c|}
\hline & $\begin{array}{l}\text { Analysis } \\
\text { of the unit }\end{array}$ & Method of measurement & range & $\begin{array}{c}\text { Accuracy of } \\
\text { measurement }\end{array}$ \\
\hline \multirow{4}{*}{$\begin{array}{c}\text { Direct } \\
\text { mining } \\
\text { analysis unit }\end{array}$} & $\mathrm{CO}(\mathrm{L})$ & $\begin{array}{l}\text { Non-spectral infrared method } \\
\text { (NDIR) }\end{array}$ & 0-5000 РPM & $\begin{array}{c}\text { Plus or minus } \\
1 \% \mathrm{FS}\end{array}$ \\
\hline & $\mathrm{CO}(\mathrm{H})$ & $\begin{array}{l}\text { Non-spectral infrared method } \\
\text { (NDIR) }\end{array}$ & $0-20$ vol \% & $\begin{array}{c}\text { Plus or minus } \\
1 \% \mathrm{FS}\end{array}$ \\
\hline & $\mathrm{CO} 2$ & $\begin{array}{l}\text { Non-spectral infrared method } \\
\text { (NDIR) }\end{array}$ & $0-012$ vol \% & $\begin{array}{c}\text { Plus or minus } \\
1 \% \mathrm{FS}\end{array}$ \\
\hline & NOx & Chemiluminescence (Dual CLD) & 0-10000 PPM & $\begin{array}{c}\text { Plus or minus } \\
1 \% \mathrm{FS} \\
\end{array}$ \\
\hline \multirow{4}{*}{$\begin{array}{l}\text { Diluent bag } \\
\text { sampling } \\
\text { analysis unit }\end{array}$} & $\mathrm{CO}(\mathrm{L})$ & $\begin{array}{l}\text { Non-spectral infrared method } \\
\text { (NDIR) }\end{array}$ & 0-5000 PPM & $\begin{array}{c}\text { Plus or minus } \\
1 \% \mathrm{FS}\end{array}$ \\
\hline & $\mathrm{CO}(\mathrm{H})$ & $\begin{array}{l}\text { Non-spectral infrared method } \\
\text { (NDIR) }\end{array}$ & $0-20$ vol \% & $\begin{array}{c}\text { Plus or minus } \\
1 \% \mathrm{FS}\end{array}$ \\
\hline & $\mathrm{CO} 2$ & $\begin{array}{l}\text { Non-spectral infrared method } \\
\text { (NDIR) }\end{array}$ & $0-10$ vol \% & $\begin{array}{c}\text { Plus or minus } \\
1 \% \mathrm{FS}\end{array}$ \\
\hline & NOx & Chemiluminescence (Dual CLD) & 0-2000 РPM & $\begin{array}{c}\text { Plus or minus } \\
1 \% \mathrm{FS}\end{array}$ \\
\hline $\begin{array}{l}\text { Number of } \\
\text { particles }\end{array}$ & The PN & $\begin{array}{l}\text { Condensate particle counter } \\
\text { 12. (Condensation Particle } \\
\text { counting, CPC) }\end{array}$ & $\begin{array}{l}0-10000 \# / \\
\mathrm{cm}^{\wedge} 3\end{array}$ & $2 \% \mathrm{PT}$ \\
\hline $\begin{array}{l}\text { The exhaust } \\
\text { flow }\end{array}$ & CVS & $\begin{array}{l}\text { Full flow constant volume } \\
\text { sampling dilution system } \\
\text { (CVS-7400) }\end{array}$ & $\begin{array}{l}0 \text { to } 30 \mathrm{~m}^{\wedge} 3 / \\
\min \end{array}$ & $\begin{array}{l}\text { Plus or minus } \\
1 \% \mathrm{FS}\end{array}$ \\
\hline
\end{tabular}

It can be seen from Table 2 and Table 3 that the light vehicle emission test system and PEMS are produced by the same manufacturer, the measurement principle of the gas analysis unit is the same, the measurement accuracy is roughly the same, and the measurement principle of the PN is the same, these factors have improved the measurement accuracy verification The credibility of the test.

\section{Test plan design}

The light vehicle national VI emission regulations suggest that the PEMS measurement accuracy can be verified on the chassis dynamometer according to the type I test WLTC driving cycle before or after the RDE test. According to the type I test requirements, the 
actual benchmark laboratory equipment and PEMS should be calculated separately the difference between the measured specific emissions and the specific emissions of pollutants obtained by PEMS and the reference laboratory should meet the requirements of the regulations ${ }^{[9]}$.

Exhaust gas mass flowmeter can be compared with calibrated CVS to verify measurement accuracy ${ }^{[9]}$.

Exhaust gas is not diluted when measuring PEMS gas pollutants. The MEXA-7400DTR is equipped with a direct mining analysis unit. Both sampling methods are the same. Direct sampling can be used to verify the measurement accuracy of the PEMS gas analyzer under steady-state conditions and WLTC transient conditions. The measurement accuracy of PEMS exhaust mass flow test equipment and PN test equipment was verified by using a full-flow constant volume dilution system and a particle counter.

In summary, the verification test plan for the accuracy and linearity of PEMS measurement based on the light vehicle emission test system is divided into the following four parts:

1) Gas test comparison between PEMS and MEXA-7400DTR direct mining analyzer under steady-state conditions;

2) Comparison of PMS and CVS-7400 exhaust mass flow tests under steady-state conditions;

3) Gas test comparison between PEMS and MEXA-7400DTR direct mining analyzer under WLTC working condition;

4) Comparison between PEMS and CPC2000 particle number (PN) test under WLTC working condition.

\subsection{Comparison of GAS tests between PEMS and MEXA-7400TR dc analyzers at steady-state conditions}

During the test, the vehicles travel at constant speeds of $20 \mathrm{~km} / \mathrm{h}, 40 \mathrm{~km} / \mathrm{h}, 60 \mathrm{~km} / \mathrm{h}, 80$ $\mathrm{km} / \mathrm{h}, 100 \mathrm{~km} / \mathrm{h}$, and $120 \mathrm{~km} / \mathrm{h}$. In order to ensure the comparison, the sampling probe of the MEXA-7400DTR direct sampling and analysis unit is connected to the PNTU sampling point of the PEMS device. The sampling ports of the two gases are relatively close, and interference factors should be eliminated as much as possible. The device connection mode is shown in Figure 1.

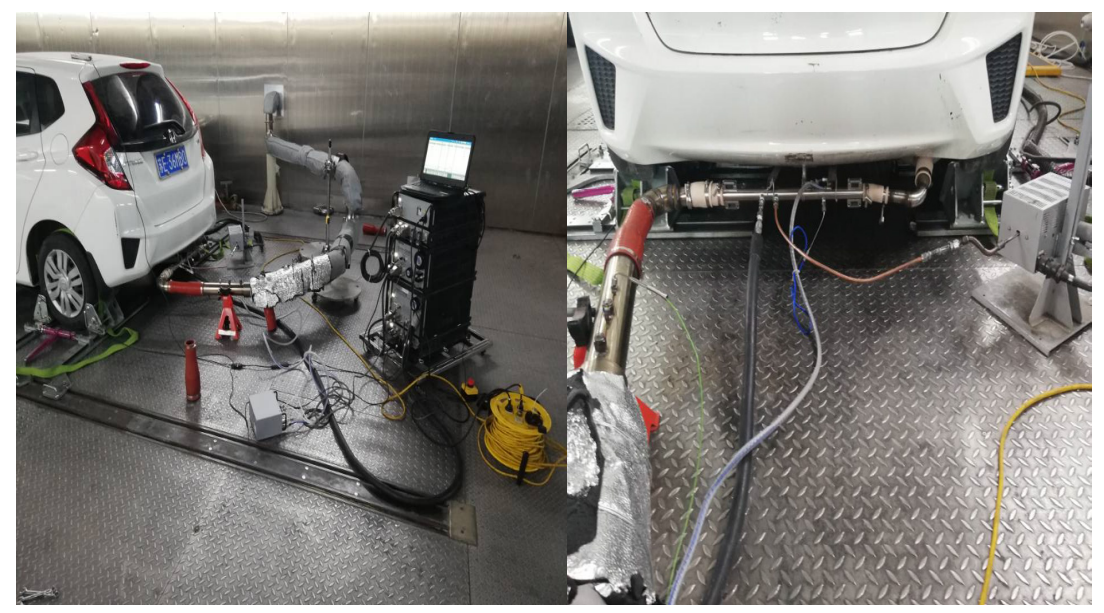

Fig. 1. Connection mode of sampling probe in PEMS and MEXA-7400DTR direct acquisition Analyzer. 


\subsection{Comparison between PEMS and CVS-7400 exhaust mass flow test under steady-state conditions}

During the test, the vehicle speed is carried out at the same speed of $20 \mathrm{~km} / \mathrm{h}, 40 \mathrm{~km} / \mathrm{h}, 60$ $\mathrm{km} / \mathrm{h}, 80 \mathrm{~km} / \mathrm{h}, 100 \mathrm{~km} / \mathrm{h}$ and $120 \mathrm{~km} / \mathrm{h}$. In the test, the PEMS and MEXA-7400DTR sample probes were connected in the same way and at steady-state conditions as in the gas comparison test between the PEMS and MEXA-7400TR direct gas analyzers. Since PEMS measures the volume of the original exhaust gas of the vehicle without dilution, cvS-7400 measures the volume of exhaust gas after dilution with diluted air. In order to verify the accuracy of exhaust mass flow measured by PEMS, the diluted exhaust volume and dilution coefficient measured by CVS-7400 are used here to convert the diluted exhaust volume into the original exhaust volume of the car. Finally, the volume flow of PEMS and CVS-7400 is converted into exhaust mass flow for comparison.

\subsection{Comparison of GAS tests between PEMS and MEXA-7400DTR for WLTC conditions}

The vehicle runs in the WLTC cycle. In the test, the PEMS and MEXA-7400DTR sample probes were connected in the same way and at steady-state conditions as in the gas comparison test between the PEMS and MEXA-7400TR direct gas analyzers.

\subsection{WLTC condition, PEMS and CPC 2000 particle quantity (PN) test comparison}

The vehicle runs in the WLTC cycle. During the test, the SAMPLING probe of PEMS equipment particulate matter quantity (PN) and the sampling probe of CPC 2000 were connected to the same point in the dilution channel of the full-flow dilution constant volume sampling system, and then entered into the PEMS and CPC 2000 respectively through the tee, ensuring the consistency of sample gas. The device connection mode is shown in Figure 2.

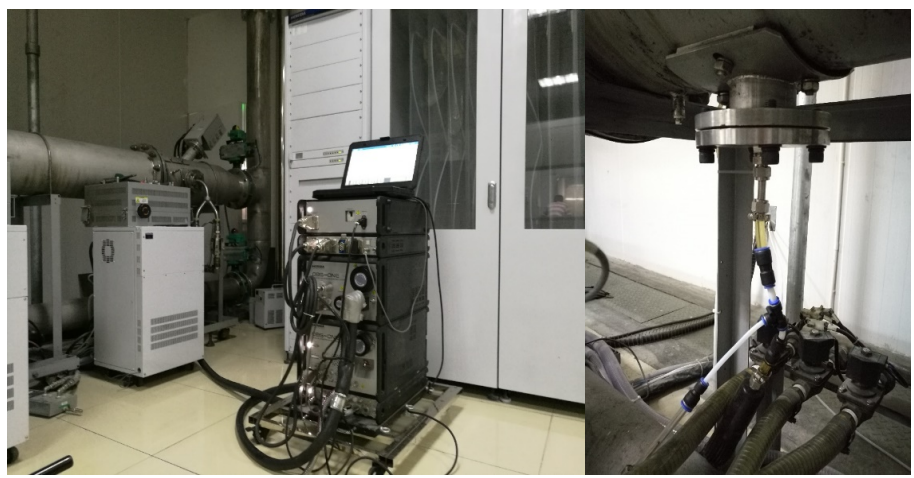

Fig. 2. Connection mode of PEMS and CPC 2000 sampling probe.

\section{Test results and analysis}

The gas measurement method of PEMS is wet-based measurement, so the measured CO, $\mathrm{CO} 2$, NOx concentrations are wet-based concentrations. MEXA-7400DTR test system CO, $\mathrm{CO} 2$ measurement method is dry-based measurement, NOx is wet-based measurement, so when comparing the test results, you need to convert the $\mathrm{CO}, \mathrm{CO} 2$ wet-based concentration 
measured by PEMS to dry-based concentration. According to the requirements of laws and regulations in the data analysis, the driving distance of the vehicle is measured by the chassis dynamometer. Before the test, the gas analysis units of PEMS and MEXA-7400DTR are calibrated, and the PN measurement unit is checked for zero point and status.

\subsection{Comparison of gas test results between PEMS and MEXA-7400DTR direct extraction analyzers under steady-state conditions}

1) Under steady-state conditions, $\mathrm{CO}$ transient data is shown in Figure 3.

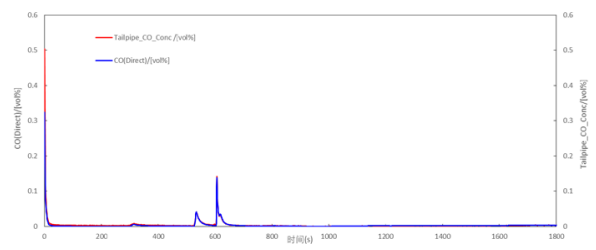

Fig. 3. Transient data of $\mathrm{CO}$ in steady-state operating conditions.

2) Under steady-state conditions, NOx transient data is shown in Figure 4.

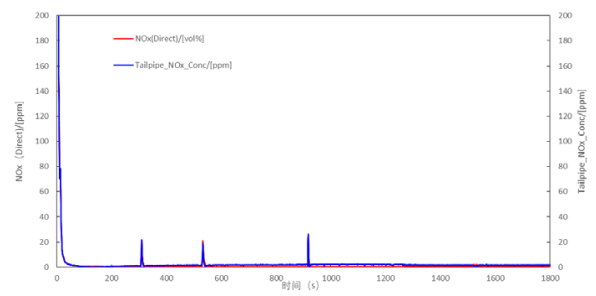

Fig. 4. Transient data of NOx in steady-state operating conditions.

3) Under steady-state conditions, the $\mathrm{CO} 2$ transient data are shown in Table 5.

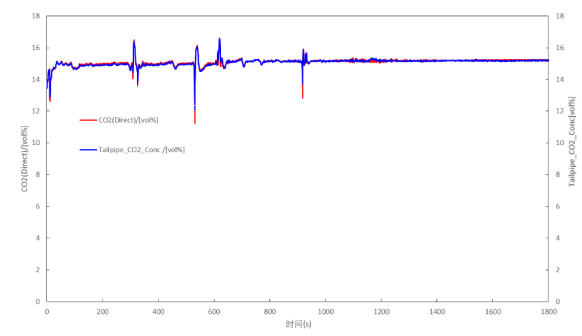

Fig. 5. Transient data of $\mathrm{CO} 2$ under steady-state conditions.

The gas test results of PEMS and MEXA-7400DTR at steady-state conditions are shown in Table 4.

Table 4. Gas test results for PEMS and MEXA-7400DTR direct - extraction analyzers.

\begin{tabular}{cccccccc}
\hline $\begin{array}{c}\text { Compare the } \\
\text { project }\end{array}$ & $\mathrm{CO} /(\mathrm{mg})$ & $\mathrm{CO} 2 /(\mathrm{mg})$ & $\mathrm{NOx} /(\mathrm{mg})$ & $\begin{array}{c}\mathrm{CO} \\
(\mathrm{mg} / \mathrm{km})\end{array}$ & $\begin{array}{c}\mathrm{CO} 2 \\
(\mathrm{mg} / \mathrm{km})\end{array}$ & $\begin{array}{c}\mathrm{NOx} \\
(\mathrm{mg} / \mathrm{km})\end{array}$ & $\begin{array}{c}\text { Fuel consumption } \\
(\mathrm{L} / 100 \mathrm{~km})\end{array}$ \\
\hline $\begin{array}{c}\text { Direct } \\
\text { production } \\
\text { analyzer }\end{array}$ & $\begin{array}{c}1022.9 \\
0\end{array}$ & $\begin{array}{c}4654659 \\
21\end{array}$ & 61.52 & 28.57 & $\begin{array}{c}130004 \\
46\end{array}$ & 1.72 & 5.49 \\
PEMS & 967.10 & $\begin{array}{c}4700000 \\
00\end{array}$ & 67.00 & 27.00 & $\begin{array}{c}133300 . \\
00\end{array}$ & 1.90 & 5.60
\end{tabular}




\begin{tabular}{cccccccc}
$\begin{array}{c}\text { Absolute } \\
\text { error }\end{array}$ & 55.80 & 45340.79 & 5.48 & 1.57 & 3295.54 & 0.18 & 0.11 \\
$\begin{array}{c}\text { Relative } \\
\text { error (\%) }\end{array}$ & 5.46 & 0.97 & 8.91 & 5.49 & 2.53 & 10.55 & 2.09 \\
\hline
\end{tabular}

\subsection{Comparison of test results between PEMS and CVS-7400 exhaust mass flow test under steady-state conditions}

The total exhaust mass flow rate measured by PEMS was $83536.538 \mathrm{~kg} / \mathrm{h}$, and the total exhaust mass flow rate measured by CVS-7400 was $85,884.377 \mathrm{~kg} / \mathrm{h}$, and the relative measurement error was $-2.74 \%$. The comparison results of transient exhaust mass flow are shown in FIG. 6.

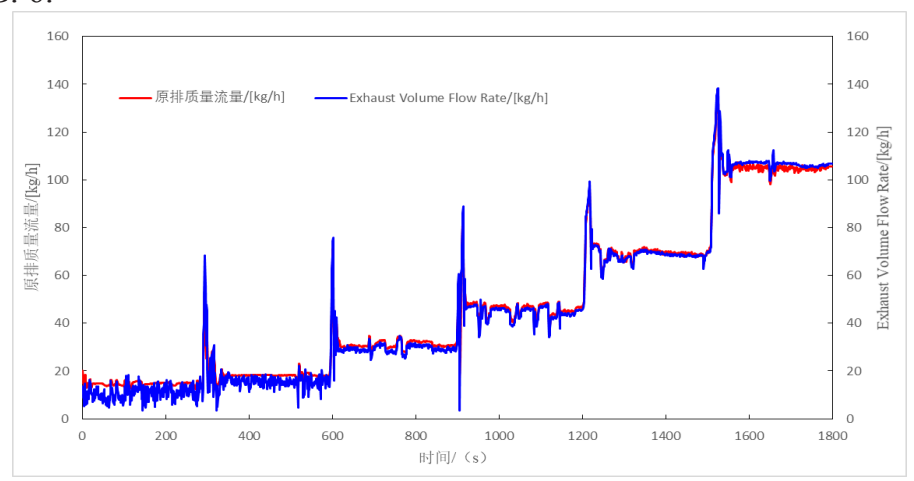

Fig. 6. Transient data of exhaust mass flow in steady-state operating conditions.

It can be seen from Figure 6 that under steady-state operating conditions, the transient exhaust flow measured by PEMS has good consistency with the transient exhaust flow of the vehicle's original row measured by CVS-7400, but there are differences. The graph reflects that the instantaneous flow rate measured by the CVS-7400 changes linearly relatively stable, while the transient exhaust flow rate measured by PEMS has good linearity at high speed, and the flow rate continuously fluctuates in a small range at low speed. This is caused by the two the measurement principle is different.

According to the requirements of the regulations, it is necessary to verify the linearity of the exhaust mass flow calculated by the reference laboratory and the exhaust mass flow measured by PEMS. According to the displacement of the test vehicle, PEMS selects the Pitot tube A model during the test. The maximum exhaust volume measurement range is 2 $\mathrm{m}^{3} / \mathrm{min}$. During the linearity verification process, regulations require that the test points with a flow rate lower than $10 \%$ of the maximum flow rate be excluded. At a fixed frequency of at least $1.0 \mathrm{~Hz}$, perform linear regression fitting on the verification signal and the reference signal. The linearity verification results are shown in Figure 7. 


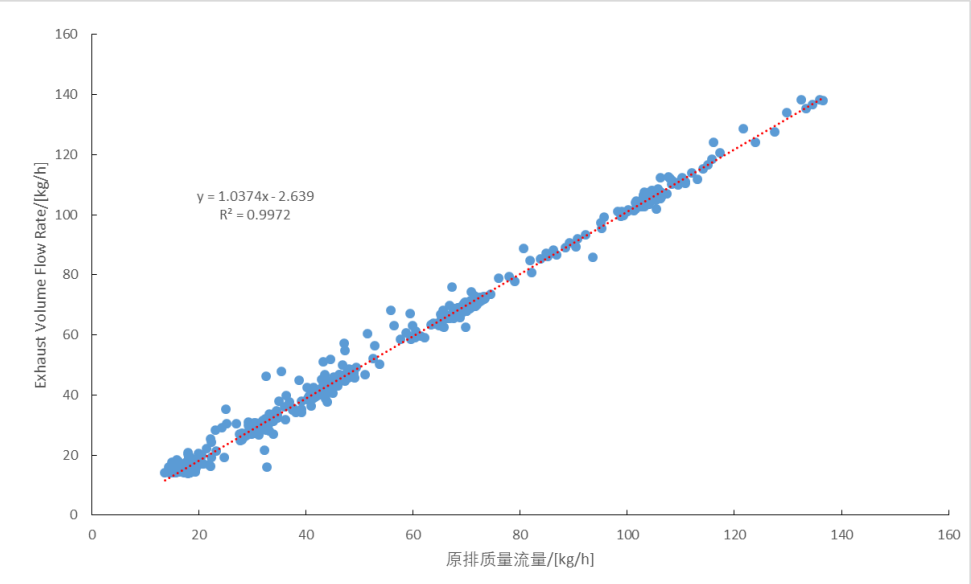

Fig. 7. Calculation and PEMS measurement of exhaust mass flow linearity.

\subsection{Comparison of gas test results between PEMS and MEXA-7400DTR for WLTC conditions}

1) WLTC operating condition and CO transient data are shown in Figure 8.

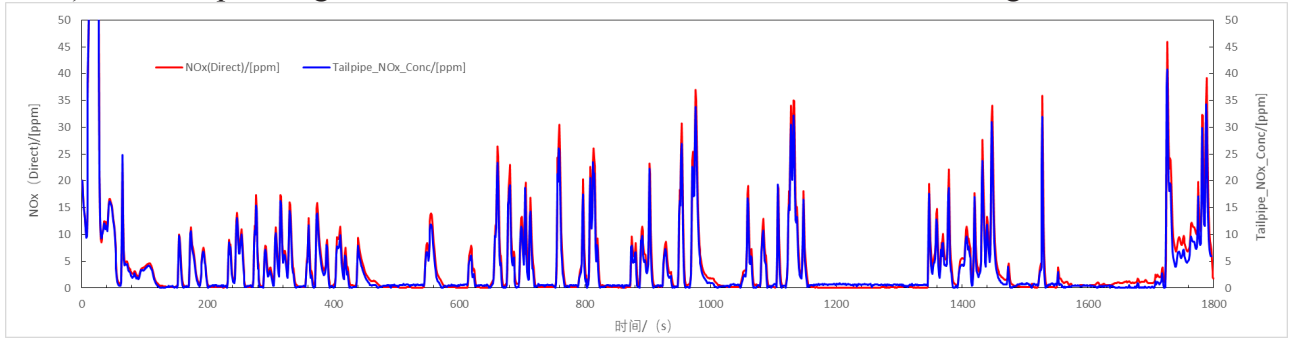

Fig. 8. TRANSIENT CO data of WLTC operating condition.

2) WLTC operating condition and NOx transient data are shown in Figure 9.

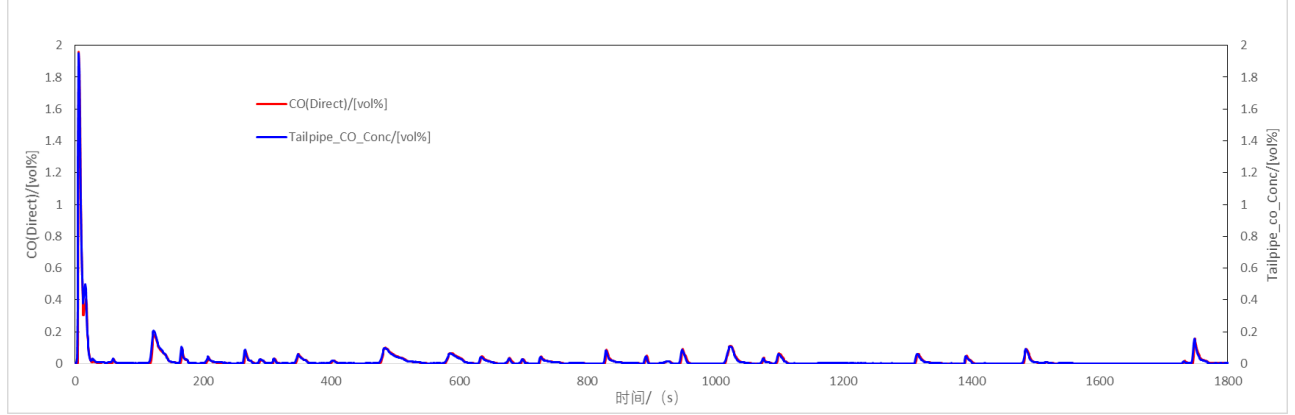

Fig. 9. Transient data of NOx in WLTC operating condition.

3) WLTC condition, CO2 transient data are shown in Figure 10. 


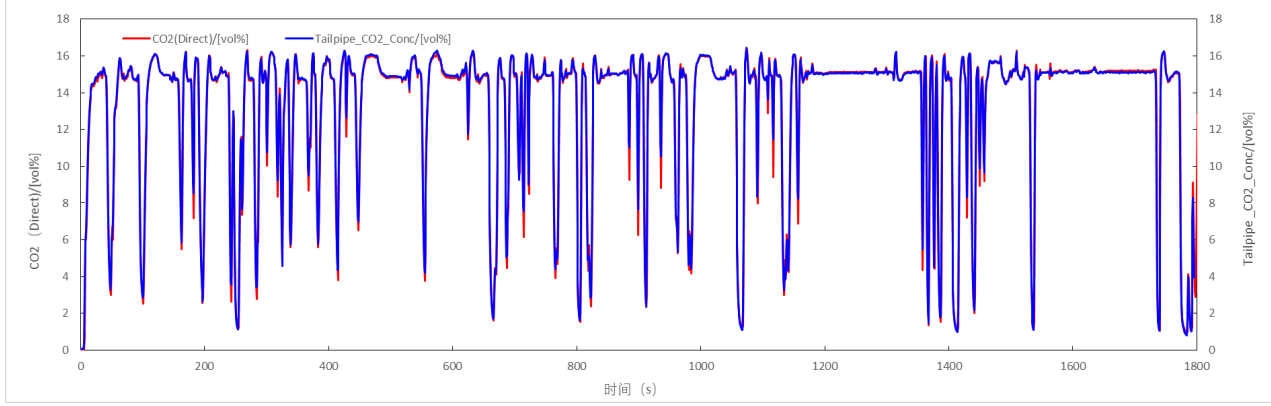

Fig. 10. TRANSIENT DATA of $\mathrm{CO} 2$ in WLTC working condition.

The gas test results of PEMS and MEXA-7400DTR for WLTC are shown in Table 5

Table 5. Gas test results for PEMS and MEXA-7400DTR direct - extraction analyzers.

\begin{tabular}{cccccccc}
\hline $\begin{array}{c}\text { Compare the } \\
\text { project }\end{array}$ & $\begin{array}{c}\mathrm{CO} \\
/(\mathrm{mg})\end{array}$ & $\begin{array}{c}\mathrm{CO} 2 \\
/(\mathrm{mg})\end{array}$ & $\begin{array}{c}\mathrm{NOx} \\
/(\mathrm{mg} \\
)\end{array}$ & $\begin{array}{c}\mathrm{CO} \\
(\mathrm{mg} / \mathrm{km}\end{array}$ & $\begin{array}{c}\mathrm{CO} 2 \\
(\mathrm{mg} / \mathrm{km})\end{array}$ & $\begin{array}{c}\mathrm{NOx} \\
(\mathrm{mg} / \mathrm{km})\end{array}$ & $\begin{array}{c}\text { Fuel } \\
\text { consumptio } \\
\mathrm{n}(\mathrm{L} / 100 \mathrm{~km})\end{array}$ \\
\hline $\begin{array}{c}\text { Direct } \\
\text { production } \\
\text { analyzer }\end{array}$ & 1876.69 & $\begin{array}{c}3339086.1 \\
2\end{array}$ & $\begin{array}{c}82.4 \\
2\end{array}$ & 80.62 & $\begin{array}{c}143449.9 \\
6\end{array}$ & 3.54 & 6.06 \\
$\begin{array}{c}\text { PEMS } \\
\text { Absolute } \\
\text { error }\end{array}$ & 144.30 & $\begin{array}{c}3449000.0 \\
0\end{array}$ & $\begin{array}{c}89.0 \\
0\end{array}$ & 86.00 & $\begin{array}{c}147100.0 \\
0\end{array}$ & 4.00 & 6.20 \\
$\begin{array}{c}\text { Relative } \\
\text { error }(\%)\end{array}$ & 7.69 & 3.29 & 7.98 & 6.67 & 2.54 & 12.96 & 2.37 \\
\hline
\end{tabular}

\subsection{WLTC condition, PEMS and CPC2000 particle number (PN) test comparison test results}

FIG. 11 and Table 6 show the transient data of PEMS and CPC 2000 particulate matter quantity $(\mathrm{PN})$ under WLTC condition.

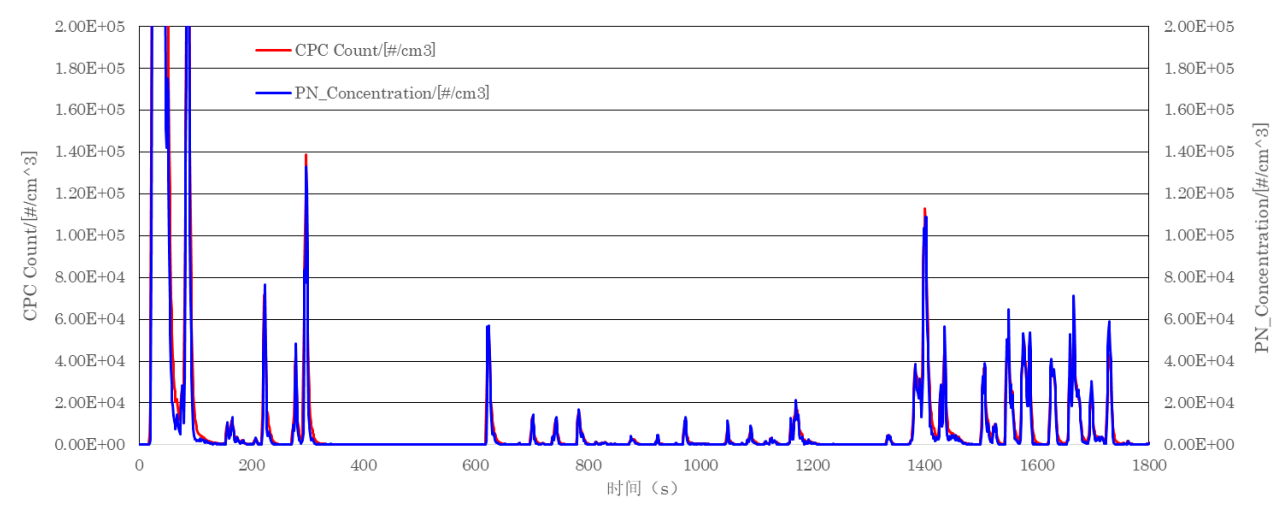

Fig. 11. Transient data of PEMS and CPC 2000 Particulate Matter quantity (PN) test.

Table 6. Comparison test results of PEMS and CPC 2000 PN.

\begin{tabular}{ccccc}
\hline Compare the project & CPC 2000 & PEMS & $\begin{array}{c}\text { Absolute } \\
\text { error }\end{array}$ & $\begin{array}{c}\text { Relative error } \\
(\%)\end{array}$ \\
\hline
\end{tabular}




\begin{tabular}{ccccc}
\hline Number of particles/(\#) & $9.27 \mathrm{e}+12$ & $7.77 \mathrm{e}+12$ & $1.5 \mathrm{e}+12$ & 16.08 \\
Number of particles/(\#//km) & $3.98 \mathrm{e}+11$ & $3.34 \mathrm{e}+11$ & $0.64 \mathrm{e}+11$ & 16.08 \\
\hline
\end{tabular}

It can be seen from the above experimental results that PEMS and light vehicle emission testing system have good consistency, and the measurement accuracy of PEMS meets the test requirements. The vehicle driving distance is measured by OBD and chassis dynamometer respectively. The comparison results of the steady-state and transient conditions and the allowable errors of regulations are shown in Table 7.

Table 7. Verification results of PEMS measurement accuracy.

\begin{tabular}{|c|c|c|c|c|c|c|c|c|c|}
\hline \multirow[b]{2}{*}{$\begin{array}{c}\text { Compare the } \\
\text { project }\end{array}$} & \multicolumn{5}{|c|}{ The steady state } & \multicolumn{4}{|c|}{ Working condition of WLTC } \\
\hline & $\begin{array}{c}\text { Dist } \\
\text { anc } \\
\mathrm{e} \\
(\mathrm{m})\end{array}$ & $\begin{array}{c}\mathrm{CO} \\
(\mathrm{mg} / \mathrm{k} \\
\mathrm{m})\end{array}$ & $\begin{array}{c}\mathrm{CO} 2 \\
(\mathrm{mg} / \mathrm{km})\end{array}$ & $\begin{array}{c}\mathrm{NOx} \\
(\mathrm{mg} / \mathrm{k} \\
\mathrm{m})\end{array}$ & $\begin{array}{l}\text { Distan } \\
\text { ce }(m)\end{array}$ & $\begin{array}{c}\mathrm{CO} \\
(\mathrm{mg} / \mathrm{k} \\
\mathrm{m})\end{array}$ & $\begin{array}{c}\mathrm{CO} 2 \\
(\mathrm{mg} / \mathrm{k} \\
\mathrm{m})\end{array}$ & $\begin{array}{c}\mathrm{NOx} \\
(\mathrm{mg} / \mathrm{k} \\
\mathrm{m})\end{array}$ & $\begin{array}{l}\mathrm{PN} \\
(\# / \\
\mathrm{km})\end{array}$ \\
\hline analyzer & $\begin{array}{c}358 \\
00\end{array}$ & $\begin{array}{c}1022 . \\
90\end{array}$ & $\begin{array}{c}4654659 \\
.21\end{array}$ & 61.52 & 23280 & 28.57 & $\begin{array}{c}13000 \\
4.46\end{array}$ & 1.72 & $\begin{array}{l}3.98 \\
\mathrm{e}+11\end{array}$ \\
\hline PEMS & $\begin{array}{c}356 \\
70\end{array}$ & $\begin{array}{c}967.1 \\
0\end{array}$ & $\begin{array}{c}4700000 \\
.00\end{array}$ & 67.00 & 23450 & 27.00 & $\begin{array}{c}13330 \\
0.00\end{array}$ & 1.90 & $\begin{array}{l}3.34 \\
\mathrm{e}+11\end{array}$ \\
\hline $\begin{array}{l}\text { Absolute } \\
\text { error }\end{array}$ & - & 55.80 & $\begin{array}{c}45340.7 \\
9\end{array}$ & 5.48 & 170 & 1.57 & $\begin{array}{c}3295 . \\
54\end{array}$ & 0.18 & $\begin{array}{l}0.64 \\
\mathrm{e}+11\end{array}$ \\
\hline $\begin{array}{l}\text { Relative } \\
\text { error (\%) }\end{array}$ & 0.36 & 5.46 & 0.97 & 8.91 & 0.72 & 5.49 & 2.53 & 10.55 & 16.08 \\
\hline $\begin{array}{l}\text { Absolute } \\
\text { error limit } \\
\quad( \pm)\end{array}$ & 250 & 150 & 10000 & 15 & 250 & 150 & 10000 & 15 & $\begin{array}{c}1 \mathrm{e}+ \\
11\end{array}$ \\
\hline $\begin{array}{l}\text { Relative } \\
\text { error limit } \\
\quad(\%)\end{array}$ & - & 15 & 10 & 15 & - & 15 & 10 & 15 & 50 \\
\hline Pass/Fail & $\begin{array}{c}\text { Pas } \\
\text { s }\end{array}$ & Pass & Pass & Pass & Pass & Pass & Pass & Pass & Pass \\
\hline
\end{tabular}

Under steady-state conditions, the comparison results of the linearity of the calculated and measured exhaust mass flow are shown in Table 8

Table 8. Comparison results of exhaust mass flow linearity.

\begin{tabular}{|c|c|c|c|c|}
\hline $\begin{array}{c}\text { Compare the } \\
\text { project }\end{array}$ & $\begin{array}{l}\text { The y-intercept of } \\
\text { the regression line }\end{array}$ & The slope & $\begin{array}{l}\text { To determine the } \\
\text { coefficient of }\end{array}$ & $\begin{array}{c}\text { The standard } \\
\text { deviation, SEE's }\end{array}$ \\
\hline Verify the values & 2.639 & 1.0374 & 0.9972 & Max $10 \%$ or less \\
\hline Regulations limit & $0.0+/-3.0 \mathrm{~kg} / \mathrm{h}$ & $\begin{array}{c}1.00+/- \\
0.075\end{array}$ & 0.90 or higher & $2.037 \%$ \\
\hline
\end{tabular}

\section{Conclusion}

As the basic research part of the vehicle emission test, this article uses the light vehicle emission test system to verify the accuracy of the PEMS gas analyzer, flow measurement equipment, and PN measurement on the chassis dynamometer under steady-state conditions and WLTC conditions, respectively. Concluded as follow:

1) Steady-state working conditions, gas test comparison results of PEMS and MEXA-7400DTR direct mining analyzer show that the relative measurement errors of gas pollutants $\mathrm{CO}, \mathrm{CO} 2, \mathrm{NOx}$ and fuel consumption are $-5.49 \%, 2.53 \%, 10.55 \%, 2.09 \%$, respectively; 
2) Steady-state operating conditions, the comparison results of PMS and CVS-7400 exhaust mass flow tests show that the relative measurement error is $-2.74 \%$, and the linearity also meets the requirements of the regulations, but the PEMS gas mass flow measurement is unstable at low speeds. Fluctuation within a certain range;

3) WLTC working conditions, the gas test comparison results of PEMS and MEXA-7400DTR direct mining analyzer show that the relative measurement errors of gas pollutants $\mathrm{CO}, \mathrm{CO} 2, \mathrm{NOx}$ and fuel consumption are $6.67 \%, 2.54 \%, 12.96 \%, 2.37 \%$;

4) WLTC working conditions, the comparison of PEMS and CPC 2000 particulate matter $(\mathrm{PN})$ test results show that the relative measurement error of $\mathrm{PN}$ is $-16.08 \%$;

5) When using PEMS for emission testing, affected by the measurement accuracy of the equipment, especially when testing low-level emission pollutants, a suitable range must be selected.

"Verification of PEMS Measurement Accuracy" (TSARI-KJ-HX/QT-201826)

\section{Reference}

1. Johnson V. Review of Vehicular Emissions Trends [R].SAE Tech Paper, 2015-01-0993.

2. Ge Yunshan, Wang Aijuan, wang meng, et al. Application of PEMS in actual road gas emission test of urban vehicles [J]. Journal of automotive safety and energy conservation, 2010, 1(2):141-145.

3. Dearth of M A, Butler J W, Colvin A, et al. Semtech D: The chassis roll evaluation of A ltd. portable emission measurement system (PEMS) [R]. SAE Tech Paper, 2005-01-06, 73 .

4. Gierczak C A, Korniski $\mathrm{T} J$, Wallington $\mathrm{T}$ J, et al.Laboratory evaluation of the Semtech-g ${ }^{\circledR}$ Portable emissions Measurement system (PEMS) for Gasoline Fueled Fueled [R]. SAE Tech Paper, 2006-01-1081

5. Xu Weijia, huang jianzhang, liu yonghong, et al. Analysis of vehicle exhaust emission characteristics based on PEMS and COPERT [J]. Environmental science and technology, 2014,37(S1):77-81.

6. Ge Yunshan, ding yan, Yin hang. Research status of actual driving emission test system for motor vehicles [J]. Journal of automotive safety and energy conservation, 2017, 8(2):111-121.

7. Dieselnet. Heavy - duty onroad engines [DB/OL]. (2016-08-01). https://dieselnet.com/standards/cycles/nte.php.

8. As regards emissions from light passenger and commercial vehicles (Euro 6) [S]. Commission regulation (EU) No. 2016/427, 03-10, 2016.

9. GB/T 118352.6 -- Emission limits and Measurement Methods for Light vehicles (China stage 6)(release)[S]. 2016.

10. Emission limits and Measurement Methods for heavy-duty Diesel Vehicles (China stage 6)[S].2018.

11. The ecological environment of the People's Republic of China. The roads mobile machine with diesel engine emission control technology and its requirements (draft) http://www.mee.gov.cn/gkml/hbb/bgth/201802/t20180224_431718.htm.2018. 